\title{
Homoharringtonine suppresses imatinib resistance via the Bcl-6/ p53 pathway in chronic myeloid leukemia cell lines
}

\author{
Qian Wang ${ }^{1}$, Wei Ding ${ }^{1}$, Yihan Ding ${ }^{1}$, Jingjing Ma ${ }^{1}$, Zhaoye Qian ${ }^{2}$, Jingxian Shao ${ }^{2}$ \\ and Yufeng $\mathbf{L i}^{1}$ \\ ${ }^{1}$ Department of Hematology, Huai'an First People's Hospital, Nanjing Medical University, Huai'an, 223300, China \\ ${ }^{2}$ Department of Oncology, Huai'an First People's Hospital, Nanjing Medical University, Huai'an, 223300, China \\ Correspondence to: Yufeng Li, email: liyufeng99@netease.com \\ Keywords: Bcl-6/p53 pathway, homoharringtonine, imatinib, drug-resistance, chronic myeloid leukemia \\ Received: March 04, $2016 \quad$ Accepted: March 08, $2017 \quad$ Published: March 30, 2017 \\ Copyright: Wang et al. This is an open-access article distributed under the terms of the Creative Commons Attribution License \\ (CC-BY), which permits unrestricted use, distribution, and reproduction in any medium, provided the original author and source \\ are credited.
}

\section{ABSTRACT}

Background: The anti-leukemic mechanism of homoharringtonine (HHT) differs from that of IM, and HHT is one of the most useful agents for use in patients with IM resistance or intolerance. The $\mathrm{Bcl}-6 / \mathrm{p} 53$ pathway has been shown to regulate the sensitivity of tumor cells to antitumor drugs. We tested whether HHT blocked the $\mathrm{Bcl}-6 / \mathrm{p} 53$ pathway in order to promote the apoptosis of IM-resistant cells in vitro and in vivo.

Results: Ph+ acute lymphoblastic leukemia (ALL) cells and IM-resistant chronic myeloid leukemia (CML) cells showed high expression of $\mathrm{Bcl}-6$ protein. Bcl-6 mediated the upregulation of p53, and and Bcl-6 induced growth inhibition of IM-resistant cells as well as its apoptosis by targeting p53. In addition, $\mathrm{Bcl}-6$ was downregulated moderately after HHT treatment in different cells. The Bcl-6 expression was significantly increased in patients with CML when compared with healthy subjects. Furthermore, the expression of $\mathrm{BCl}-6$ was higher in patients with $\mathrm{CML}$-blastic phase (CML-BP) than in those with CML-chronic phase (CML-CP).

Methods: The inhibitory effect of drugs on cell growth was detected by Cell Counting Kit-8 (CCK-8), The apoptosis rate and the cell cycle were investigated by flow cytometry. The expression of $\mathrm{Bcl}-6, \mathrm{p} 53, \mathrm{Bcl}-2$, caspase9, and caspase 3 proteins was assayed by western blot, Real- Time PCR (qPCR) detect Bcl-6 and p53 mRNA.

Conclusions: HHT can suppress the growth and induce apoptosis of IM-resistant cells, the mechanism of which is associated with blocking of the $\mathrm{Bcl}-6 / \mathrm{p5} 3$ pathway. Our results could offer a theoretical explanation for HHT use in patients with IM resistance or intolerance.

\section{INTRODUCTION}

Chronic myeloid leukemia (CML) arises from pluripotent hemopoietic stem cells with a reciprocal translocation between chromosomes 9 and 22 [1]. The chromosomal abnormality persistently activates tyrosine kinase, resulting in the activation of a downstream signaling pathway that inhibits cell apoptosis [2-4]. In 2002, the US Food and Drug Administration (FDA) approved the tyrosine kinase inhibitor (TKI) imatinib (IM) for CML treatment [5]. The international randomized study (IRIS) reported a complete hematologic remission rate of $97 \%$ [6], complete cytogenetic response rate of $63 \%$ [7], and major cytogenetic response rate of $87 \%$ [8] in newly diagnosed CML-chronic phase (CML-CP) patients after 12 months of IM treatment. Only 7\% of patients entered accelerated phase (AP) disease or blast crisis (BC) [9]. Although IM is highly effective for treating CML, it does have limitations. These include an inability to eradicate leukemia stem cells (LICs) and the occurrence of primary or secondary drug resistance [10-12]. IRIS reported an overall incidence of IM resistance of $18 \%$ at 5 years [13]. Compared with CML-CP patients, patients with progressive disease had higher drug resistance and 
relapse rates. The drug resistance rate was 75\% CML-AP and 95\% in CML-BP patients [14]. Recent studies have reported similar findings [15].

The B-cell lymphoma (Bcl-6) gene encodes a 96 $\mathrm{kD}$ nucleophosmin (NPM) that belongs to the bric-abrac tramtrack broad complex/pox virus zinc (BTB/POZ) transcription factor family [16]. The functional Bcl-6 protein is a transcription repressor containing 706 amino acids, and the inhibition of $\mathrm{Bcl}-6$ transcription results from the interaction of BTB/POZ with a number of corepressors $[17,18]$. Bcl-6 is closely associated with the occurrence and development of diffuse large B-cell lymphoma (DLBCL) and follicular lymphoma (FL) [19]; 20\%-40\% of DLBCL and $15 \%$ of FL patients have the Bcl-6 $3 \mathrm{q} 27$ chromosome translocation [20, 21]. Bcl-6 can suppress p53 expression in germinal center B-cell like DLBCL and inhibit B-cell apoptosis caused by DNA damage. Ryan et al. found that Bcl- 6 could downregulate $\mathrm{p} 53$ by binding to its promoter region [22].

The anti-leukemic mechanism of homoharringtonine (HHT) differs from that of IM, and HHT is one of the most useful agents for use in patients with IM resistance or intolerance [23]. HHT is an inhibitor for protein translation, which blocks the synthesis of protein via affecting the A site in ribosome [24]. In October 2012, the US FDA approved the use of HHT for the treatment of CML, which gave the drug widespread attention [25].

This present study investigated the effect of HHT on the proliferation, apoptosis and cell cycle of IM-resistant CML cells and involvement of the Bcl-6/p53 signaling pathway.

\section{RESULTS}

\section{The drug resistance of $\mathrm{K562} / \mathrm{G01}$ cells}

Various concentrations of IM treated K562 cells and K562/G01 cells for 24h. The K562 cells were more sensitive to IM than the K562/G01 cells. Treatment with
$0.5 \mu \mathrm{M}$ IM for $24 \mathrm{~h}$ induced more than $50 \%$ of K562 cells to the death (Figure 1A). Treatment with $9.5 \mu \mathrm{M}$ IM for 24 $\mathrm{h}$ induced more than $50 \%$ of K562/G01cells to the death (Figure 1B). Our results show that the drug resistance of K562/G01 cells is 19 times to the K562 cells, which proves that our drug resistance cells are effective.

\section{Bcl-6 regulates p53 in K562/G01 cells}

In order to observe the influence of Bcl-6 on p53, we examined Bcl-6 and p53 following treatment of K562/ G01 cells with $\mathrm{Bcl}-6$ siRNA. In cells treated with $\mathrm{Bcl}-6$ siRNA1 and siRNA2 for $48 \mathrm{~h}$, the level of Bcl- 6 mRNA was $(30.67 \pm 0.82) \%$ and $(38.74 \pm 1.76) \%$, respectively $(P<$ 0.01 ; Figure 2A). Furthermore, after $B c l-6$ siRNA treatment, the Bcl-6 protein was obviously reduced $(P<0.01$; Figure $2 \mathrm{~B}, 2 \mathrm{C}$ ), which reveals that the downregulation of Bcl6 was effective. Subsequently, p53 mRNA and protein were detected. The results showed that $\mathrm{p} 53$ protein was upregulated distinctly (Figure 2B, 2C), while the mRNA was slightly downregulated (Figure 2A). Therefore, Bcl-6 mediated the upregulation of p53 in K562/G01 cells.

\section{K562/G01 cells are sensitive to Bcl-6-induced growth inhibition and apoptosis}

After downregulation of Bcl-6, we investigated the cell growth and apoptosis of K562/G01 cells at 24, 48, and $72 \mathrm{~h}$. The results showed that downregulation of Bcl6 can inhibit K562/G01 cell growth, in a time-dependent mode (Figure 3A). The data are shown in Table 1. We also assessed the effect of Bcl-6 on cell apoptosis. After $48 \mathrm{~h}$, the apoptosis rate was $(4.50 \pm 0.17) \%,(7.23 \pm 0.25) \%$, $(30.9 \pm 1.67) \%$, and $(23.26 \pm 1.61) \%$, respectively (Figure $3 \mathrm{C}$, Table 2). Furthermore, we detected the apoptosisrelated proteins. Bcl-2 and total caspase9 were reduced, and cleaved-caspase 3 was upregulated (Figure 3B). In summary, we suggest that K562/G01 cells are sensitive to Bcl-6-induced growth inhibition and apoptosis.
A

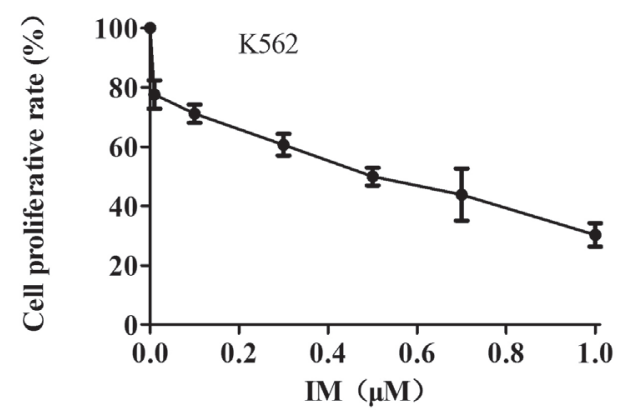

B

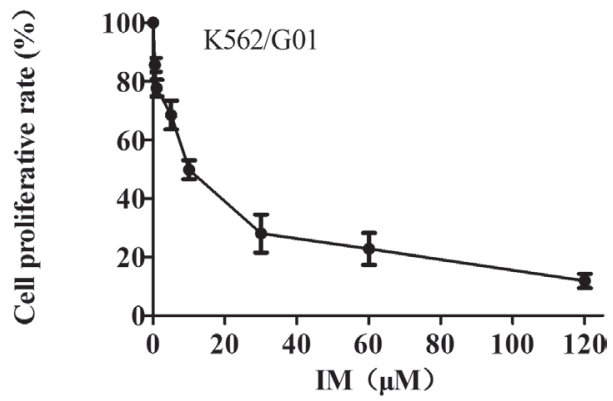

Figure 1: Cell growth inhibition and cytotoxicity of IM in K562 cells and K562/G01 cells. (A) Cell growth inhibition and viability of K562 cells. K562 cells were treated with IM at the indicated concentrations for 24 hours. (B) Cell growth inhibition and viability of K562/G01 cells. K562/G01 cells were treated with IM at the indicated concentrations for 24 hours. Cell viability was determined by CCK-8. Values shown are mean $\pm \mathrm{SD}$. Of three independent experiments. 


\section{HHT-induced K562/G01 cells growth inhibition, apoptosis and cell cycle arrest}

The cells were treated with $0,10,50,100,200$, or $400 \mathrm{nM}$ HHT for $24 \mathrm{~h}$. The results showed that HHT can inhibit K562/G01 cell growth, in a time-dependent mode (Figure 4A). It suggests that HHT could induce
K562/G01 cells growth inhibition. We also assessed the effects of HHT on cell apoptosis. In K562/G01 cells cultured with $0,50,100$, or $200 \mathrm{nM}$ HHT for $24 \mathrm{~h}$, respectively, the rate of apoptosis was $(1.93 \pm 0.15) \%$, $(35.50 \pm 1.47) \%,(48.80 \pm 1.10) \%$, and $(53.50 \pm 0.62) \%$, respectively (Figure 4C, Table 3). Furthermore, we investigated the apoptosis-related proteins: $\mathrm{Bcl}-2$ and

A
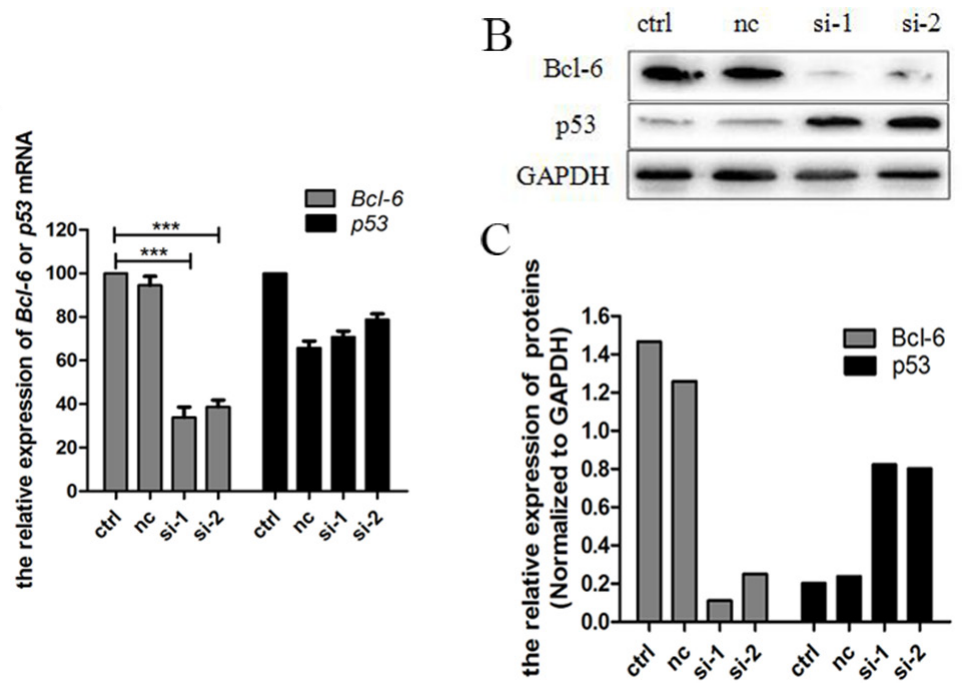

Figure 2: Bcl-6 mediated the upregulation of p53 in K562/G01 cells. (A) K562/G01 cells treated with Bcl-6 siRNA1 and siRNA2 for $48 \mathrm{~h}$. The levels of $B c l-6$ mRNA were $(30.67 \pm 0.82) \%$ and $(38.74 \pm 1.76) \%$ respectively, compared with control. The $p 53$ mRNA was slightly downregulated. (B) K562/G01 cells treated with Bcl-6 siRNA1 and siRNA2 for 48h. The Bcl-6 protein reduced obviously. And si-1 and si-2 show that 553 protein was upregulated distinctly. $(\mathbf{C})$ The relative expression of Bcl-6 and p53 proteins. The expression of mRNA was determined by qPCR. The expression of proteins were determined by western blot. Values shown are mean $\pm \mathrm{SD}$. Of three independent experiments.

A

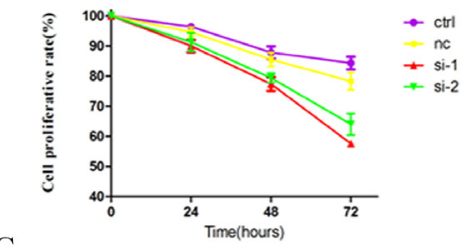

C
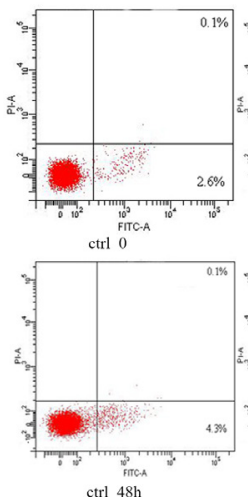

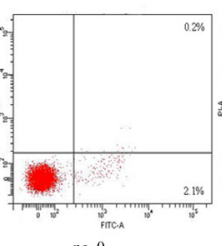

ne 0

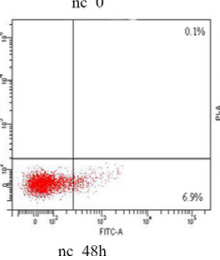

B

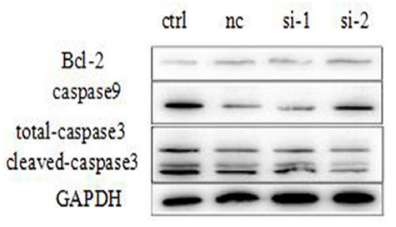

Figure 3: K562 /G01 cells are sensitive to Bcl-6-induced growth inhibition and apoptosis. (A) Cell growth inhibition and viability of K562/G01 cells. K562/G01 cells treated with Bcl-6 siRNA1 and siRNA2 for 24h, 48h, 72h. (B) The expression of apoptosis proteins. K562/G01 cells treated with Bcl-6 siRNA1 and siRNA2 for 48h. Bcl-2, caspase9, caspase3 express. (C) Apoptosis of K562/G01 cells. K562/G01 cells treated with Bcl-6 siRNA1 and siRNA2 for 48h. Cell viability was determined by CCK-8. The expression of proteins were determined by western blot. PE annexin V detect apoptosis. Values shown are mean $\pm \mathrm{SD}$. Of three independent experiments. 
Table 1: Cell proliferative rate of K562/G01 cells treated with $B c l-6$ siRNA1 and siRNA2 respectively $(n=3$, mean \pm SD)

\begin{tabular}{lcccc}
\hline \multicolumn{5}{c}{ Cell proliferative rate (\%) } \\
\hline Time(h) & ctrl & nc & si-1 & si-2 \\
\hline 0 & 100.00 & 100.00 & 100.00 & 100.00 \\
24 & $96.46 \pm 0.45$ & $94.70 \pm 0.87$ & $90.03 \pm 1.17$ & $91.35 \pm 1.76$ \\
48 & $87.86 \pm 1.16$ & $85.53 \pm 1.34$ & $77.39 \pm 1.31 * *$ & $79.41 \pm 0.92 * *$ \\
72 & $84.33 \pm 1.20$ & $78.33 \pm 1.66$ & $57.57 \pm 0.03 * * *$ & $64.04 \pm 2.04 * *$ \\
\hline
\end{tabular}

$* * \mathrm{P}<0.01, * * * \mathrm{P}<0.001$, compared with ctrl.

Table 2: Apoptosis rate of K562/G01 cells treated with $\mathrm{Bcl}-6$ siRNA1 and siRNA2 respectively $(\mathrm{n}=3$, mean \pm SD)

\begin{tabular}{lccccc}
\hline \multicolumn{5}{c}{ Apoptosis rate (\%) } \\
\hline Time(h) & ctrl & nc & si-1 & si-2 \\
\hline 0 & $2.80 \pm 0.10$ & $2.46 \pm 0.15$ & $2.10 \pm 0.26$ & $1.96 \pm 0.20$ \\
48 & $4.50 \pm 0.17$ & $7.23 \pm 0.25$ & $30.90 \pm 1.67 * * *$ & $23.26 \pm 1.61 * *$ \\
\hline
\end{tabular}

$* * \mathrm{P}<0.01, * * * \mathrm{P}<0.001$, compared with ctrl.

total caspase9 were reduced, and cleaved-caspase3 was upregulated (Figure 4B). We observed that HHT could induce apoptosis in IM-resistant cells, and that HHT inhibited the cell cycle progression of K562/G01 cells. The cell cycle distribution was analyzed by flow cytometry after treatment with HHT at different doses and for different time. The cells were treated with 0,50 , 100 , or $200 \mathrm{nM} \mathrm{HHT}$ for $24 \mathrm{~h}$. The results suggested that HHT blocks the G1 phase change from the G2 period. The cell number was distinctly decreased after HHT treatment, when compared with control $(P<$ 0.001 ; Figure 4D, 4F). The cells were treated with 100 nM HHT for 24, 48, or $72 \mathrm{~h}$. The results suggested that HHT blocks the G1 phase change from the G2 period, as shown previously. The cell number was distinctly decreased after an increased time, when compared with control $(P<0.001$; Figure 4E, 4G).

\section{Expression of Bcl-6 in bone marrow}

Twenty CML-CP patients and ten CML-BP patients were the volunteers for samples. Table 4 is the specific information for patients. The average value of Bcl-6 mRNA in healthy controls, CML-CP and CMLBP patients was $(0.10 \pm 0.02),(0.83 \pm 0.03),(0.86 \pm 0.04)$, respectively (Figure $5 \mathrm{~B}$ ). Whereas the average value of Bcl-6 protein in healthy controls, CML-CP and CMLBP patients was $(0.17 \pm 0.02),(0.57 \pm 0.12),(0.91 \pm 0.08)$, respectively (Figure $5 \mathrm{~A}$ ). The western blot findings are shown in Figure 5C and 5D. Above data indicates that the level of Bcl-6 protein is higher at CML-BP patients than CML-CP patients.

\section{Bcl-6 protein in $\mathrm{Ph}+$ cells, and HHT blockage of the Bcl-6/p53 pathway}

We tested Bcl-6 protein in K562, K562/G01, KU812, SUP-B15, and 293 T cells after incubation with HHT at 0,50 or $100 \mathrm{nM}$ for $24 \mathrm{~h}$. Western blot detect the expressions of Bcl-6 and p53 proteins. The results showed that the level of Bcl-6 protein declined in K562/G01 cells, K562cells, KU812 cells, $293 \mathrm{~T}$ cells, and SUP-B15 cells, accompanied by a distinct rise in p53 (Figure 6A-6E). These results strongly suggest that HHT specifically reduces Bcl-6 in cells, and its downstream target p53. To confirm the baseline value of Bcl-6 in CML cells, we selected five cell lines in which to detect Bcl-6 protein. The level of Bcl-6 protein, from high to low, was found to vary in K562/G01 cells, SUP-B15 cells, K562 cells, KU812 cells, and 293T cells (Figure 6F).

\section{Effect of HHT on $\mathrm{Bcl}-6$ and p53 mRNA expression}

Real-Time PCR (qPCR) detect the levels of mRNA. With regard to the expression of Bcl-6 and p53 mRNA, the results differed from those for the expression of proteins. In KU812 and SUP-B15 cells, the level of Bcl-6 mRNA was reduced in a dose-dependent mode after treating with HHT, accompanied by a distinct 
rise in $p 53$ (Figure 7A, 7D). In 293T cells, the amount of $\mathrm{Bcl}-6$ mRNA reduced in a dose-dependent mode after treating with HHT, whereas p53 was upregulated irregularly (Figure 7C). In K562/G01 cells, the Bcl-6 was downregulated compared with control, but there was a dose-dependent rise in Bcl-6 mRNA, as in K562 cells (Figure 7B, 7E). The level of $p 53$ changed irregularly in K562/G01 cells and K562 cells (Figure 7B, 7E). To confirm the baseline value of $B c l-6$ in CML cells, we selected five cell lines for detection expression of $\mathrm{Bcl}-6$ mRNA. The level of expression of Bcl- $6 \mathrm{mRNA}$, from high to low, was found to vary in SUP-B15 cells, K562/ G01 cells, K562 cells, KU812 cells, and 293T cells (Figure 7F).

\section{DISCUSSION}

In 2011, Pellicano $F$ et al described the pharmacological inhibition of Bcl-6 as a new strategy to eradicate LICs in CML [26]. Christian et al. reported that CML cells upregulated Bcl-6 in response to treatment with a TKI. They also confirmed that Bcl-6 directly repressed p53 in human CML cells [27]. Duy et al. reported that the growth of TKI-resistant $\mathrm{Ph}+$ acute lymphoblastic leukemia $(\mathrm{Ph}+\mathrm{ALL})$ cells was related to Bcl-6 activity and the pathogenesis of ALL was closely associated with the Bcl6/Arf/p53 pathway signals [28]. We showed that Bcl-6 was over expressed in K562/G01 cells, which indicates Bcl-6 overexpression is closely linked to TKI resistance in CML.

$$
\begin{aligned}
& \text { A } \\
& \text { }
\end{aligned}
$$
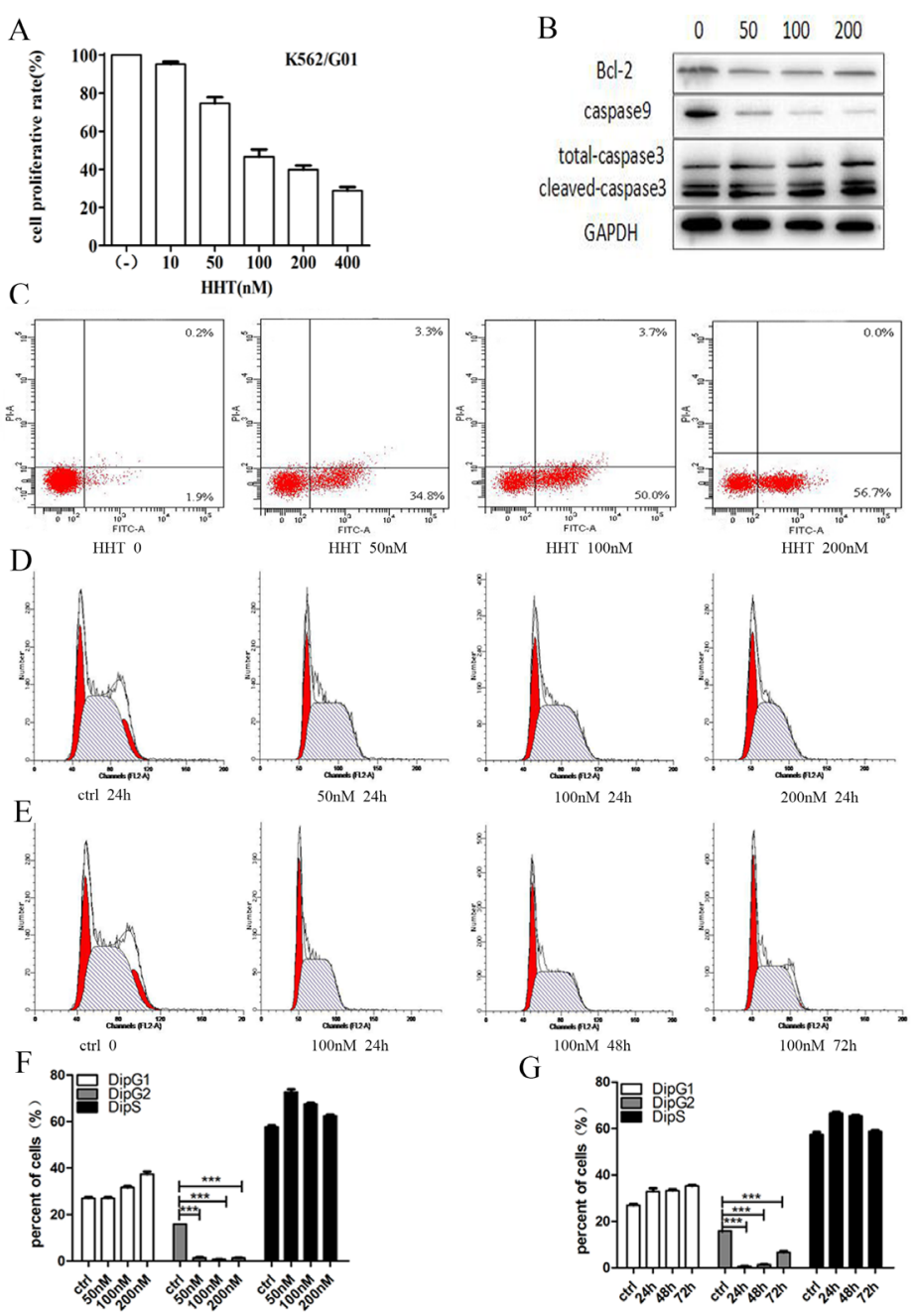

G

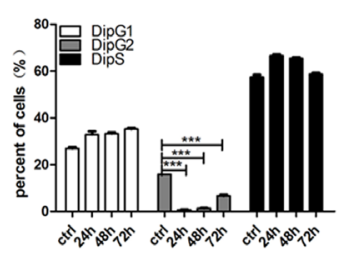

Figure 4: Cell growth inhibition, apoptosis and cell cycle arrest of HHT in K562/G01 cells. (A) K562/G01 cells were treated with HHT at the indicated concentrations for 24 hours. The concentrations were 0, 10, 50, 100, 200, $400 \mathrm{nM}$. (B) The expression of apoptosis proteins. K562/G01 cells treated with HHT 0, 50nM, $100 \mathrm{nM}, 200 \mathrm{nM}$ for 24h. Bcl-2, caspase9, caspase3 express. (C) Apoptosis of K562/G01 cells. K562/G01 cells treated with HHT 0, 50nM, $100 \mathrm{nM}, 200 \mathrm{nM}$ for 24h. (D) Cycle of K562/G01 cells. K562/G01 cells treated with HHT 0, 50nM, 100 nM, 200nM for 24h. (E) Cycle of K562/G01 cells. K562/G01 cells treated with $100 \mathrm{nM} \mathrm{HHT}$ for 24h, 48h, 72h. (F) Cycle of K562/ G01 cells. K562/G01 cells treated with HHT 0, 50nM, 100 nM, 200nM for 24h. (G) Cycle of K562/G01 cells. K562/G01 cells treated with 100 $\mathrm{nM}$ HHT for $24 \mathrm{~h}, 48 \mathrm{~h}, 72 \mathrm{~h}$. Cell viability was determined by CCK-8. The expression of proteins were determined by western blot. PE annexin $\mathrm{V}$ detect apoptosis. Flow cytometry detect cycle. Values shown are mean $\pm \mathrm{SD}$. Of three independent experiments. 
Table 3: Apoptosis rate of K562/G01 cells treated with HHT 0, 50nM, 100nM, 200nM respectively (n=3, mean $\pm \mathrm{SD}$ )

\begin{tabular}{lcccc}
\hline \multicolumn{5}{c}{ Apoptosis rate (\%) } \\
\hline Time(h) & $\mathbf{0}$ & $\mathbf{5 0 n M}$ & $\mathbf{1 0 0 n M}$ & $\mathbf{2 0 0 n M}$ \\
\hline 24 & $1.93 \pm 0.15$ & $35.50 \pm 1.47 * *$ & $48.80 \pm 1.10^{* *}$ & $53.50 \pm 0.62 * * *$ \\
\hline
\end{tabular}

$* * \mathrm{P}<0.01, * * * \mathrm{P}<0.001$, compared with $\mathrm{ctrl}$.

Table 4: Patient characteristics

\begin{tabular}{lccc}
\hline Characteristic & & CML-CP patients (n=20) & CML-BP patients (n=10) \\
\hline Gender & Male & 7 & 5 \\
& Female & 13 & 5 \\
Age (years) & Median & 44 & 53.5 \\
& Range & $23-64-64$ \\
WBC, $\times 109 / \mathrm{L}$ & Median & 42.16 & 180.64 \\
& Range & $2-299.88$ & $10-434.6$ \\
Hemoglobin, g/L & Median & 108 & 101 \\
Platelet count, $\times 109 / \mathrm{L}$ & Range & $69-147$ & $79-129$ \\
& Median & 300.5 & 829 \\
\hline
\end{tabular}

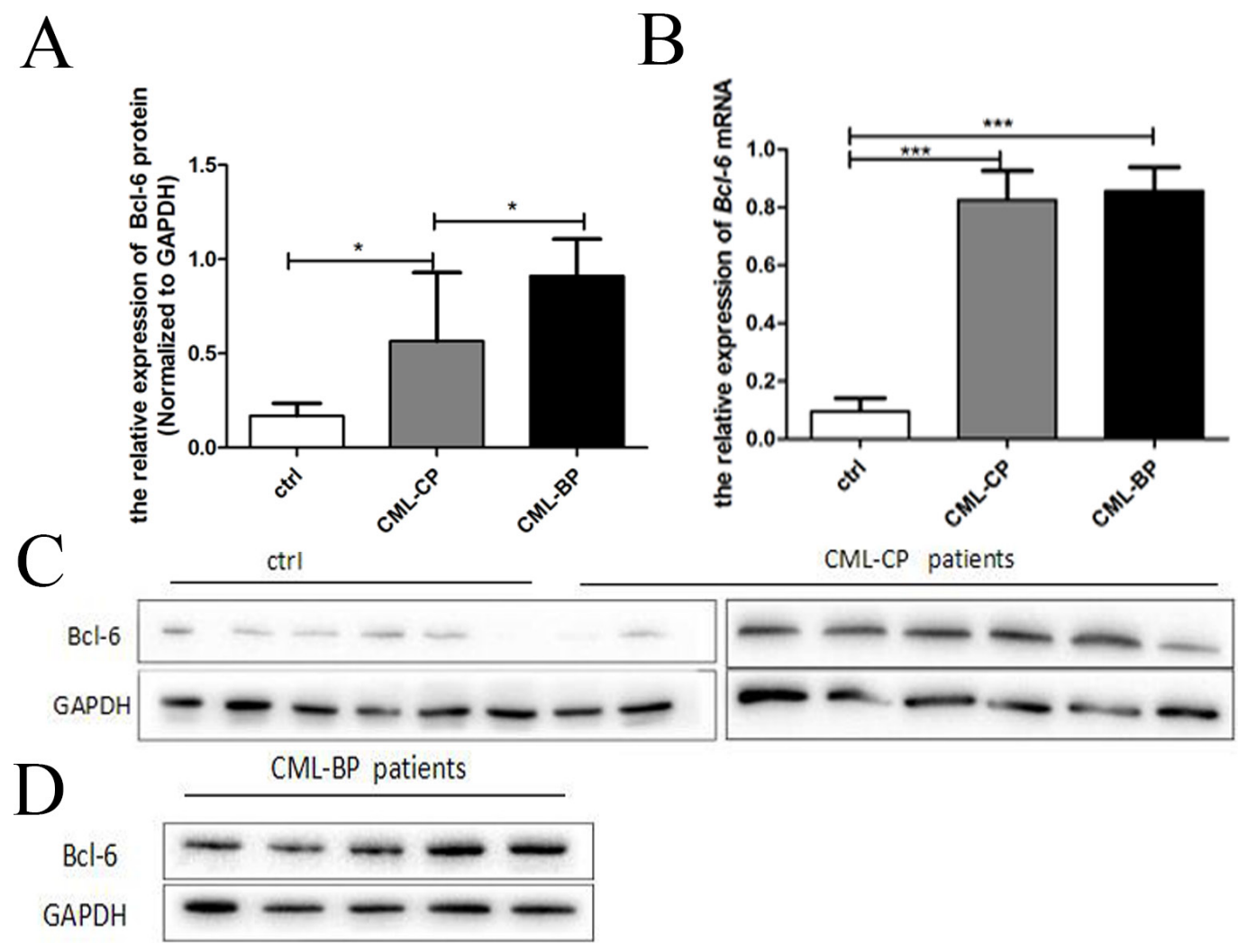

Figure 5: The expression of Bcl-6 in CML-CP and CML-BP patients. (A) qRT-PCR analysis of the relative expression of $B c l-6$ mRNA in CML-CP patients and CML-BP patients and controls. (B) Western blot analysis of Bcl-6 protein in CML-CP patients and CMLBP patients and controls. (C) Western blot analysis of Bcl-6 protein in CML-CP patients and controls. (D) Western blot analysis of Bcl-6 protein in CML-BP patients. Values shown are mean $\pm \mathrm{SD}$. 

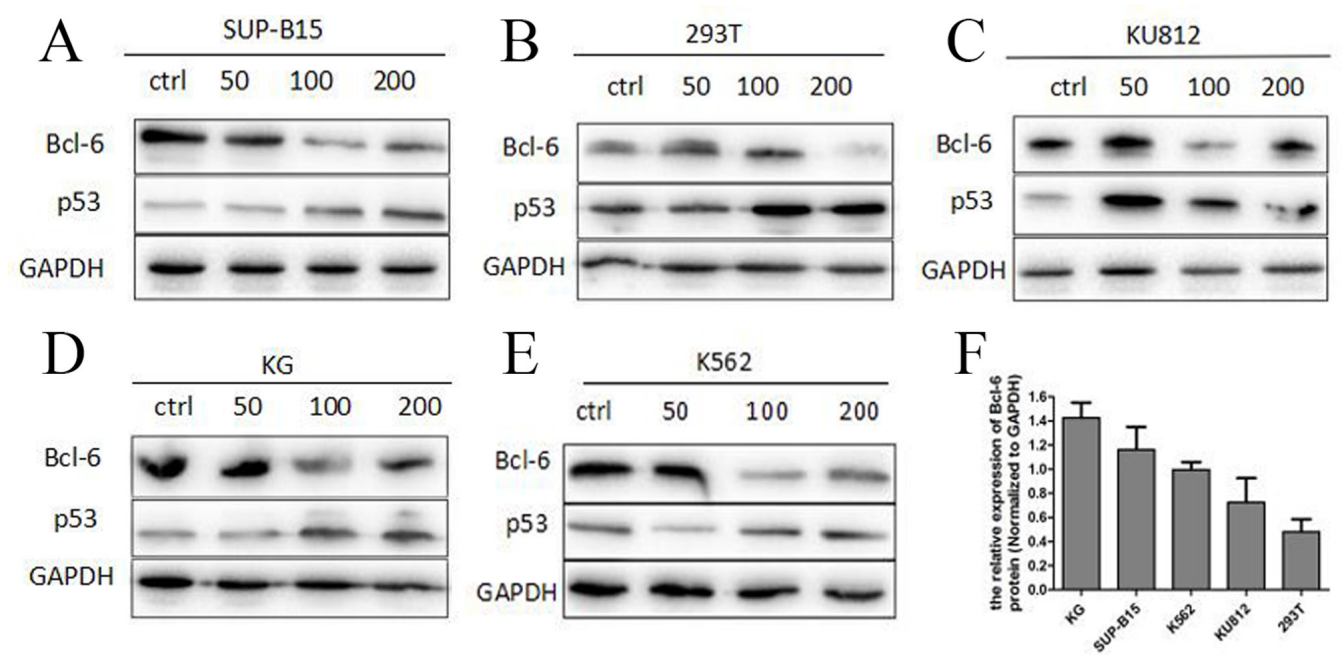

Figure 6: High expression of Bcl-6 protein in Ph+ cells and HHT blocked the Bcl-6/p53 pathway. (A) SUP-B15 cells were treated with HHT 0, 50nM, $100 \mathrm{nM}, 200 \mathrm{nM}$ for 24h. (B) 293T cells were treated with HHT 0, 50nM, $100 \mathrm{nM}, 200 \mathrm{nM}$ for 24h. (C) KU812 cells were treated with HHT 0, 50nM, $100 \mathrm{nM}, 200 \mathrm{nM}$ for 24h. (D) K562/G01 cells were treated with HHT 0, 50nM, $100 \mathrm{nM}, 200 \mathrm{nM}$ for 24h. (E) K562 cells were treated with HHT 0, 50nM, $100 \mathrm{nM}, 200 \mathrm{nM}$ for 24h. (F) The Bcl-6 expression of 5 cells without treatment. The expression of proteins were determined by Western blot. Values shown are mean \pm SD. Of three independent experiments.
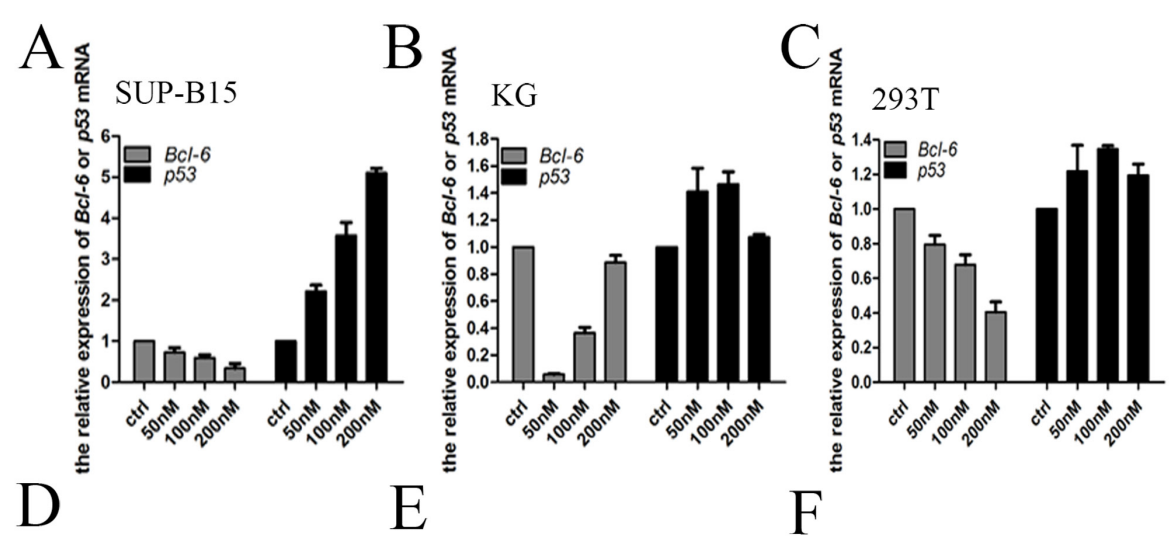

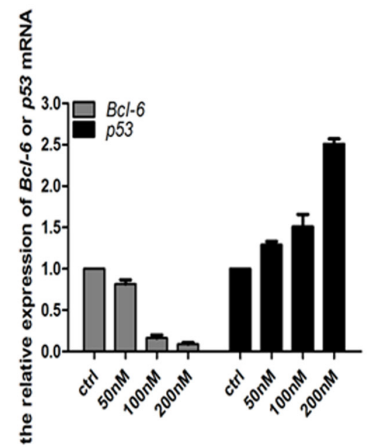

KU812

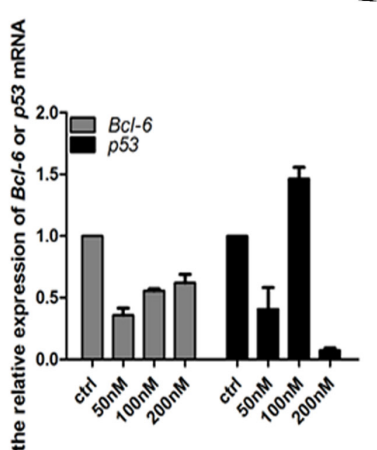

K562

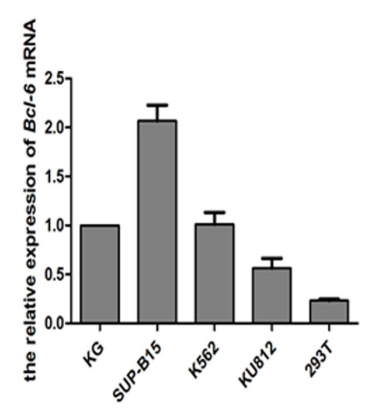

Figure 7: HHT effect the Bcl-6 and p53 mRNA expression. (A) SUP-B15 cells were treated with HHT 0, 50nM, $100 \mathrm{nM}, 200 \mathrm{nM}$ for 24h. (B) K562/G01 cells were treated with HHT 0, 50nM, $100 \mathrm{nM}, 200 \mathrm{nM}$ for 24h. (C) 293T cells were treated with HHT 0, 50nM, 100 nM, 200nM for 24h. (D) KU812 cells were treated with HHT 0, 50nM, $100 \mathrm{nM}, 200 \mathrm{nM}$ for 24h. (E) K562 cells were treated with HHT 0, $50 \mathrm{nM}, 100 \mathrm{nM}, 200 \mathrm{nM}$ for 24h. (F) The $\mathrm{Bcl}-6$ expression of 5 cells without treatment. The expression of mRNA were determined by qRT$\mathrm{PCR}$. Values shown are mean $\pm \mathrm{SD}$. Of three independent experiments. 
siRNA sequences

Bcl-6 siRNA1(sense)

Bcl-6 siRNA1(antisense)

Bcl-6 siRNA2(sense)

Bcl-6 siRNA2(antisense)
5'-GCAGUUUAGAGCCCAUAAATT-3'

5'-UUUAUGGGCUCUAAACUGCTT-3'

5'-GCAAUAUCUAUUCACCCAATT-3'

5'-UUGGGUGAAUAGAUAUUGCTT-3'
Bcl-6 plays an important part in the growth and differentiation of $\mathrm{B}$ cells, is associated with pathogenesis of DLBCL [29], and promotes CML stem cell survival by inhibiting apoptosis. It has been reported that Bcl-6 can repress $p 53$-dependent apoptosis because of DNA damage [30], and that MicroRNA-187 can induce apoptosis of DLBCL cells by downregulating Bcl-6 expression [31]. Qiang et al. demonstrated the oncogenetic properties of Bcl-6 in breast cancer, and concluded that Bcl-6 could be a target in the treatment of breast cancer [32]. In this study, we showed that low Bcl-6 expression inhibited growth and apoptosis of IM-resistant K562 cells, and more importantly, mediated high expression of $\mathrm{p} 53$, which induced apoptosis of tumor cells.

HHT is currently used as an effective treatment of hematological diseases, especially ALL [33]. We demonstrated that HHT inhibited growth, caused cell cycle arrest of IM-resistant K562 cells, and blocked the Bcl-6/ p53 pathway.

Although we know Bcl-6 is associated with IMresistant CML, additional studies are needed to describe causes. Our research showed that the effects of HHT on drug resistance involved inhibition of the Bcl-6/p53 pathway.

\section{MATERIALS AND METHODS}

\section{Bone marrow samples and patients}

At the Department of Hematology, Huai'an First People's Hospital, Nanjing Medical University, Huai'an, China, bone marrow (BM) samples were collected from patients between April 2015 and May 2016. From patients with newly diagnosed CML in the chronic phase (CML-CP, $\mathrm{n}=20$ ) and those in blast crisis (CML-BP, $n$ $=10$ ), we acquired the bone marrow samples. Healthy control samples were from 11 volunteers without CML. Mononuclear cells from the samples were isolated by Ficoll-Hypaque density gradient centrifugation, after that put in $-80^{\circ} \mathrm{C}$. The Ethics Committee of Nanjing Medical University approve the research. The IM was obtained from Selleck and the HHT from MedChem Express (MCE, Shanghai, China).

\section{Transfection and cell culture}

The CML cell lines K562 and K562/G01 (Cell Repository, Chinese Academy of Science, Shanghai,
China) was incubated at $37^{\circ} \mathrm{C}$, with $95 \%$ air and $5 \% \mathrm{CO}$ in RPMI 1640 (Gibco, USA) containing 10\% fetal bovine serum (FBS, Gibco). The human CML cell line KU812 (Basic Medical Institute, Chinese Academy of Medical Sciences, Beijing, China) was incubated at $37^{\circ} \mathrm{C}$, with 95\% air and 5\% $\mathrm{CO}_{2}$ in RPMI 1640 containing 10\% FBS. The human Ph+ ALL cell line SUP-B15 (Cell Repository, Chinese Academy of Science, Shanghai, China)was incubated at $37^{\circ} \mathrm{C}$, with $95 \%$ air and $5 \% \mathrm{CO}_{2}$ in Iscove's Modified Dulbecco's Medium (IMDM, Gibco) containing $10 \%$ FBS. The human renal epithelial cell line 293T (Cell Repository, Chinese Academy of Science, Shanghai, China) was cultured at $37^{\circ} \mathrm{C}$, with $95 \%$ air and $5 \% \mathrm{CO}_{2}$ in DMEM (Gibco) containing 10\% FBS. Ficoll density gradient centrifugation (TBD Science, Tianjin, China) isolate blast cells. The K562/G01 cells were transfected with $\mathrm{Bcl}-6$ siRNA using Lipofectamine 2000 (Invitrogen, USA) for 48 h. Bcl-6 siRNA was synthesized by GenePharmagps in Shanghai. The sequences for the $\mathrm{Bcl}$ 6 siRNA1 were:5'-GCAGUUUAGAGCCCAUAAATT-3' (sense), 5'-UUUAUGGGCUCUAAACUGCTT-3' (antisense). Those for Bcl-6 siRNA2 were: 5'-GCAAUAUCUAUUCACCCAATT-3' (sense), 5'-UUGGGUGAAUAGAUAUUGCTT-3' (antisense).

\section{Real-time PCR and RNA extraction}

The total RNA in cells and human BM samples was extracted using TRIzol (Invitrogen, USA). The mRNA isolation kit extracted total RNA following the reagent supplies manual. For the mRNA quantitative analysis, reverse-transcribed the RNA using the NCode ${ }^{\mathrm{TM}}$ SYBR Green kit (Invitrogen, USA). All qPCR was carried out with the Bio-Rad CFX96. qPCR arrays were obtained from SABiosciences and used according to the reagent supplies manual. The comparative threshold cycle $(\mathrm{Ct})$ method was used to analyze every sample. The levels of expression of Bcl-6 and p53 were normalized to that of $G A P D H$. The PCR primer sequences were for $B c l-6$ : 5'-TCCAGTCCCCACTCACTCAC-3' (forward) and 5'-TTGCTCAAAACCAAATGAGCACT-3' (reverse); for $p 53$ : 5'-TTATGGCGGGAGGTAGACTG-3' (forward) and 5'-GTTCCGAGAGCTGAATGAGG-3' (reverse); for GAPDH: 5'-ACCAGCCTCAAGATCATCAGC-3' (forward) and 5'-TGCTAAGCAGTTGGTGGTGC-3' (reverse). The expression change calculate relative to the control (2- $\Delta \Delta \mathrm{Ct})$. 


\begin{tabular}{lc}
\hline & primer sequences \\
\hline Bcl-6(forward) & $5^{\prime}$-TCCAGTCCCCACTCACTCAC-3' \\
Bcl-6(reverse) & $5^{\prime}$-TTGCTCAAAACCAAATGAGCACT-3' \\
$p 53$ (forward) & $5^{\prime}$-TTATGGCGGGAGGTAGACTG-3' \\
$p 53$ (reverse) & $5^{\prime}$-GTTCCGAGAGCTGAATGAGG-3' \\
GAPDH (forward) & $5^{\prime}$-ACCAGCCTCAAGATCATCAGC-3' \\
GAPDH (reverse) & $5^{\prime}$-TGCTAAGCAGTTGGTGGTGC-3' \\
\hline
\end{tabular}

\section{Western blot analysis}

RIPA lysis buffer was used to isolate proteins (Beyotime, Shanghai, China), and the Bradford method determine protein concentrations. Proteins $(20 \mu \mathrm{g})$ were divided by SDS-polyacrylamide gel electrophoresis (SDS-PAGE, Beyotime) and transferred onto PVDF membranes (Millipore, USA). After $2 \mathrm{~h}$ blocking in 5\% bovine serum albumin (BSA, Vicmed, Xuzhou, China), the membranes were overnight incubated in primary antibody, diluted at $4{ }^{\circ} \mathrm{C}$ in $5 \%$ BSA.

The primary antibodies were:anti-Bcl-6 (1:1000, Abcam, USA), anti-caspase 3 (1:1000, Proteintech, USA), and anti-GAPDH (1:5000, Bioworld), anti-p53 (1:1000, Proteintech), anti-caspase9 (1:1000, Bioworld, Shanghai, China). Washing, then incubating the membranes with Horseradish Peroxidase (HRP) -conjugated rat anti- rabbit immunoglobulin (1/10000) (1:5000, Bioworld) for $1 \mathrm{~h}$, diluted in 5\% BSA. After washing, the secondary antibody was visualized by an enhanced chemiluminescence kit (Vicmed).

\section{Flow cytometry for apoptotic analysis}

PE Annexin $V$ \& PI staining (BD Biosciences, USA) evaluate apoptosis. Cells $\left(10^{6}\right)$ use PBS (Gibco) to wash twice and in binding buffer resuspend. Working solution was put into the cell suspension, cells were incubated 15 minutes at room temperature by the reagent supplies manual. Flow cytometry determine the apoptotic cells percentage.

\section{Flow cytometry for cell cycle analysis}

Cells were assessed by PI staining (BD Biosciences). Cells $\left(10^{6}\right)$ use PBS (Gibco) washed twice and were resuspended in PBS (Gibco) once. 70\% prechilled ethanol fix cells overnight at $4^{\circ} \mathrm{C}$, washed with prechilled PBS, and handled with $300 \mu \mathrm{l}$ staining solution containing $50 \mu \mathrm{g} / \mathrm{ml}$ PI and $50 \mu \mathrm{g} / \mathrm{ml}$ RNase A in dark for 30 minutes in turn. Then, DNA content was measured via FACSCalibur flow cytometry (BD Biosciences). The data were analyzed with the ModFit DNA analysis program.

\section{CCK-8 assay}

CCK8 (Dojindo, Tokyo, Japan) analyze the tolerance IM concentrations in two cells. The two cells were plated into 96-well plates at $1 \times 10^{4}$ cells/well in $100 \mu \mathrm{l}$ agent. For pre-incubation $24 \mathrm{~h}$, IM were added at various doses. In every test cells treated with the same concentrations of dimethyl sulfoxide (DMSO) were contained. Controls are undisposed cells. Inhibition rate was calculated as [1-(OD treated - OD blank $) /($ OD control - OD blank $)] \times 100 \%$.

\section{Statistical analysis}

SPSS 20.0 statistical software analyzed the statistical. The mean of three independent tests are represented by values and values are demonstrated as mean \pm SD. An independent-samples $t$ test was analyzed the compare of the proliferation and apoptosis of cells following IM or HHT intervention. A $P$ value $<0.05$ was the accepted level for significance.

\section{ACKNOWLEDGMENTS}

This work was supported by the Science Foundation of Jiangsu Huai'an (HAS2015026).

\section{CONFLICTS OF INTEREST}

The authors declare no conflicts of interest.

\section{REFERENCES}

1. Goldman JM, Melo JV. Chronic myeloid leukemiaadvances in biology and new approaches to treatment. N Engl J Med. 2003; 349:1451-64.

2. Jangamreddy JR, Panigrahi S, Lotfi K, Yadav M, Maddika S, Tripathi AK, Sanyal S, Łos MJ. Mapping of apoptininteraction with BCR-ABL1, and development of apoptinbased targeted therapy. Oncotarget. 2014; 5:7198-211. doi: 10.18632/oncotarget.2278.

3. Carrà G, Torti D, Crivellaro S, Panuzzo C, Taulli R, Cilloni D, Guerrasio A, Saglio G, Morotti A. The BCR-ABL/NF- $\kappa$ B signal transduction network: a long lasting relationship in 
Philadelphia positive Leukemias. Oncotarget. 2016; 7:6628798. doi: 10.18632/oncotarget.11507.

4. Naka K, Jomen Y, Ishihara K, Kim J, Ishimoto T, Bae EJ, Mohney RP, Stirdivant SM, Oshima H, Oshima M, Kim DW, Nakauchi H, Takihara Y, et al. Dipeptide species regulate p38MAPK-Smad3 signalling to maintain chronic myelogenous leukaemia stem cells. Nat Commun. 2015; 6:8039.

5. Jabbour E, Kantarjian H. Chronic myeloid leukemia: 2014 update on diagnosis, monitoring, and management. Am J Hematol. 2014; 89:547-56.

6. Kantarjian HM, O’Brien S, Cortes JE, Shan J, Giles FJ, Rios MB, Faderl SH, Wierda WG, Ferrajoli A, Verstovsek S, Keating MJ, Freireich EJ, Talpaz M. Complete cytogenetic and molecular responses to interferon-alphabased therapy for chronic myelogenous leukemia are associated with excellent long-term prognosis. Cancer. 2003; 97:1033-41.

7. Hochhaus A, Druker B, Sawyers C, Guilhot F, Schiffer CA, Cortes J, Niederwieser DW, Gambacorti-Passerini C, Stone RM, Goldman J, Fischer T, O'Brien SG, Reiffers JJ, et al. Favorable long-term follow-up results over 6 years for response, survival, and safety with imatinib mesylate therapy in chronic-phase chronic myeloid leukemia after failure of interferon-alpha treatment. Blood. 2008; 111:1039-43.

8. Hughes TP, Hochhaus A, Branford S, Müller MC, Kaeda JS, Foroni L, Druker BJ, Guilhot F, Larson RA, O'Brien SG, Rudoltz MS, Mone M, Wehrle E, et al. Long-term prognostic significance of early molecular response to imatinib in newly diagnosed chronic myeloid leukemia: an analysis from the International Randomized Study of Interferon and STI571 (IRIS). Blood. 2010; 116:3758-65.

9. Druker BJ, Guilhot F, O'Brien SG, Gathmann I, Kantarjian H, Gattermann N, Deininger MW, Silver RT, Goldman JM, Stone RM, Cervantes F, Hochhaus A, Powell BL, et al. Fiveyear follow-up of patients receiving imatinib for chronic myeloid leukemia. N Engl J Med. 2006; 355:2408-17.

10. Quintás-Cardama A, Kantarjian HM, Cortes JE. Mechanisms of primary and secondary resistance to imatinib in chronic myeloid leukemia. Cancer Control. 2009; 16:122-31.

11. Li L, Xu N, Zhang JF, Xu LL, Zhou X, Huang BT, Li YL, Liu XL. EphB4/ephrinB2 Contributes to Imatinib Resistance in Chronic Myeloid Leukemia Involved in Cytoskeletal Proteins. Int J Med Sci. 2016; 13:365-73.

12. Brümmendorf TH, Cortes JE, Khoury HJ, Kantarjian HM, Kim DW, Schafhausen P, Conlan MG, Shapiro M, Turnbull K, Leip E, Gambacorti-Passerini C, Lipton JH. Factors influencing long-term efficacy and tolerability of bosutinib in chronic phase chronic myeloid leukaemia resistant or intolerant to imatinib. Br J Haematol. 2016; 172:97-110.
13. Tamascar I, Ramanarayanan J. Targeted treatment of chronic myeloid leukemia: role of imatinib. Onco Targets Ther. 2009; 2:63-71.

14. Garg RJ, Kantarjian H, O’Brien S, Quintás-Cardama A, Faderl S, Estrov Z, Cortes J. The use of nilotinib or dasatinib after failure to 2 prior tyrosine kinase inhibitors: long-term follow-up. Blood. 2009; 114:4361-68.

15. Radich JP, Kopecky KJ, Appelbaum FR, Kamel-Reid S, Stock W, Malnassy G, Paietta E, Wadleigh M, Larson RA, Emanuel P, Tallman M, Lipton J, Turner AR, et al. A randomized trial of dasatinib $100 \mathrm{mg}$ versus imatinib 400 $\mathrm{mg}$ in newly diagnosed chronic-phase chronic myeloid leukemia. Blood. 2012; 120:3898-905.

16. Chang CC, Ye BH, Chaganti RS, Dalla-Favera R. BCL6, a POZ/zinc-finger protein, is a sequence-specific transcriptional repressor. Proc Natl Acad Sci USA. 1996; 93:6947-52.

17. Ci W, Polo JM, Melnick A. B-cell lymphoma 6 and the molecular pathogenesis of diffuse large B-cell lymphoma. Curr Opin Hematol. 2008; 15:381-90.

18. Albagli-Curiel O. Ambivalent role of BCL6 in cell survival and transformation. Oncogene. 2003; 22:507-16.

19. Duan S, Cermak L, Pagan JK, Rossi M, Martinengo C, di Celle PF, Chapuy B, Shipp M, Chiarle R, Pagano M. FBXO11 targets BCL6 for degradation and is inactivated in diffuse large B-cell lymphomas. Nature. 2012; 481:90-93.

20. Li Y, Wang GP, Xi YF, Wang JF, Bai W. [State of chromosome 3q27 and different subtypes of diffuse large B-cell lymphoma and their prognostic correlation]. [Article in Chinese]. Zhonghua Bing Li Xue Za Zhi. 2009; 38:231-36.

21. Jardin F, Gaulard P, Buchonnet G, Contentin N, Leprêtre S, Lenain P, Stamatoullas A, Picquenot JM, Duval C, Parmentier F, Tilly H, Bastard C. Follicular lymphoma without $\mathrm{t}(14 ; 18)$ and with BCL-6 rearrangement: a lymphoma subtype with distinct pathological, molecular and clinical characteristics. Leukemia. 2002; 16:2309-17.

22. Phan RT, Dalla-Favera R. The BCL6 proto-oncogene suppresses p53 expression in germinal-centre B cells. Nature. 2004; 432:635-39.

23. Kantarjian HM, Talpaz M, Santini V, Murgo A, Cheson B, O'Brien SM. Homoharringtonine: history, current research, and future direction. Cancer. 2001; 92:1591-605.

24. Gürel G, Blaha G, Moore PB, Steitz TA. U2504 determines the species specificity of the A-site cleft antibiotics: the structures of tiamulin, homoharringtonine, and bruceantin bound to the ribosome. J Mol Biol. 2009; 389:146-56.

25. Kantarjian HM, O'Brien S, Cortes J. Homoharringtonine/ omacetaxine mepesuccinate: the long and winding road to food and drug administration approval. Clin Lymphoma Myeloma Leuk. 2013; 13:530-33.

26. Pellicano F, Holyoake TL. Assembling defenses against therapy-resistant leukemic stem cells: Bcl6 joins the ranks. J Exp Med. 2011; 208:2155-58. 
27. Hurtz C, Hatzi K, Cerchietti L, Braig M, Park E, Kim YM, Herzog S, Ramezani-Rad P, Jumaa H, Müller MC, Hofmann WK, Hochhaus A, Ye BH, et al. BCL6-mediated repression of p53 is critical for leukemia stem cell survival in chronic myeloid leukemia. J Exp Med. 2011; 208:2163-74.

28. Duy C, Hurtz C, Shojaee S, Cerchietti L, Geng H, Swaminathan S, Klemm L, Kweon SM, Nahar R, Braig M, Park E, Kim YM, Hofmann WK, et al. BCL6 enables Ph+ acute lymphoblastic leukaemia cells to survive BCR-ABL1 kinase inhibition. Nature. 2011; 473:384-88.

29. Staudt LM, Dave S. The biology of human lymphoid malignancies revealed by gene expression profiling. Adv Immunol. 2005; 87:163-208.

30. Vogelstein B, Lane D, Levine AJ. Surfing the p53 network. Nature. 2000; 408:307-10.
31. Huang F, Jin Y, Wei Y. MicroRNA-187 induces diffuse large B-cell lymphoma cell apoptosis via targeting BCL6. Oncol Lett. 2016; 11:2845-50.

32. Wu Q, Liu X, Yan H, He YH, Ye S, Cheng XW, Zhu GL, Wu WY, Wang XN, Kong XJ, Xu XC, Lobie PE, Zhu T, Wu ZS. B-cell lymphoma 6 protein stimulates oncogenicity of human breast cancer cells. BMC Cancer. 2014; 14:418.

33. Jin J, Wang JX, Chen FF, Wu DP, Hu J, Zhou JF, Hu JD, Wang JM, Li JY, Huang XJ, Ma J, Ji CY, Xu XP, et al. Homoharringtonine-based induction regimens for patients with de-novo acute myeloid leukaemia: a multicentre, open-label, randomised, controlled phase 3 trial. Lancet Oncol. 2013; 14:599-608. 